\title{
Hydro-plankton characteristics and their relationship with sardine and anchovy distributions on the French shelf of the Bay of Biscay
}

\author{
PIERRE PETITGAS ${ }^{1}$, JACQUES MASSE ${ }^{1}$, PAUL BOURRIAU ${ }^{1}$, PIERRE BEILLOIS ${ }^{1}$, \\ JEAN PIERRE BERGERON ${ }^{1}$, DANIEL DELMAS ${ }^{2}$, ALAIN HERBLAND ${ }^{2}$, \\ NOUSSITHE KOUETA ${ }^{3}$, JEAN MAIRE FROIDEFOND ${ }^{4}$ and MARIA SANTOS 5 \\ ${ }^{1}$ IFREMER, BP 21105, 44311 cdx 3, Nantes, France. E-mail: pierre.petitgas@ifremer.fr \\ ${ }^{2}$ CREMA, BP 5, 17137 L'Houmeau, France. \\ ${ }^{3}$ Université de Caen, Esplanade de la paix, Biologie et technologie marine, 14032 Caen, France. \\ ${ }^{4}$ Université Bordeaux I, DGO / EPOC, avenue des facultés, 33405 cdx, Talence, France. \\ ${ }^{5}$ AZTI, Fisheries department, Herrera Kaia, Portualdea z/g, 20110 Pasajes, Spain.
}

\begin{abstract}
SUMMARY: The spatial pattern in hydro-plankton and fish distributions and their relationship were analysed based on the spring 2000 fisheries acoustic survey. The importance of this survey was that it was a multi-disciplinary platform which collected an extensive set of parameters in the hydro-plankton leading to a potentially finer description of hydro-plankton conditions and fish habitats. More than 50 variables were measured on a grid of stations, in four compartments of the ecosystem: hydrology, nutrients, primary producers and meso-zooplankton. First, a joint analysis of all hydro-plankton compartments was performed using multiple factor analysis (MFA). The method was used to estimate a compromise factorial space common to all compartments in which the stations were grouped by hierarchical clustering. The groups were represented spatially and a strong spatial pattern was evidenced. The fish and their spawned eggs were sampled along transect lines using acoustics and CUFES (continuous underway fish egg samplers). The distribution of the fish and their eggs was analysed in relation to the hydro-plankton groups of stations and difference in fish density across hydro-plankton conditions was tested by a pair-wise multiple comparison procedure. Anchovy was associated with a lesser number of hydro-plankton conditions than sardine. Eggs of both species were also associated with a lesser number of conditions than the fish. Finally, the gain provided by using the extensive set of hydro-plankton parameters for mapping large-scale hydro-plankton conditions was analysed in comparison with the situation in which a small set of parameters was available. The extensive set of parameters allowed more hydro-plankton conditions to be identified but only in the coastal area and not on the shelf. Size fractionated chlorophyll was determinant for tracking river plume hydro-plankton condition. However, the fish did not respond to the variety of the coastal hydro-plankton conditions.
\end{abstract}

Keywords: spatial pattern, multiple factor analysis, habitats, hydro-plankton, fish-environment relationship.

RESUMEN: CARACTERÍSTICAS HIDRO-PLANCTÓNICAS Y SU RELACIÓN CON LAS DISTRIBUCIONES DE SARDINA Y ANCHOA EN LA PLATAFORMA FRANCESA DEL GOLFO DE VIZCAYA. - Este artículo analiza la relación espacial entre los peces pelágicos y su medio ambiente utilizando datos de la campaña acústica francesa del año 2000. Esta campaña fue multidisciplinaria y permitió la colección de una lista extensa de parámetro en el hidro-plancton. Mas de 50 variables fueron muestreadas sobre la misma red de estaciones. Estas variables se agrupan en cuatro compartimientos del ecosistema: hidrología, nutrientes y materia en suspensión, bacterias y fitoplancton, mesozooplancton. En primer lugar se hizo una análisis conjunto a todas las variables reagrupadas en los cuatros compartimientos aplicando el método MFA (Análisis Factorial Múltiple). El método permitió estimar el espacio factorial común a todos los compartimientos en el que se hizo un agrupamiento de las estaciones. Los grupos tenían una distribución espacial bien estructurada. Durante la campaña, los peces fueron muestreados sobre líneas de muestreo usando el método acústico y sus huevos fueron muestreado al mismo tiempo con la bomba CUFES (continuous underway fish egg sampler). Las diferencias de abundancia de peces y de sus huevos, relativas a los grupos del hidro-plancton, se comprobaron estadísticamente. La anchoa estaba limitada a grupos de hidro-plancton particulares mientras que la sardina no lo estaba. Las puestas de las dos especies estaban limitadas a menos grupos que los adultos. El beneficio de usar una lista extensiva de variables en el hidro-plancton fue analizado. La clorofila por clases de 
tamaño era determinante en identificar grupos de hidro-plancton relacionados con las plumas de los ríos. Pero el pez no estaba relacionado solamente con estos grupos.

Palabras clave: estructura espacial, análisis factorial múltiple, hábitat, hidro-plancton, relación pez-medio ambiente.

\section{INTRODUCTION}

Fisheries resource monitoring surveys provide a platform for monitoring the ecosystem on a large spatial scale and allow patterns to be characterised in the geographical distribution of the fish as well as in that of some environmental parameters. Taking the fish distribution as a dependent variable and the environmental parameters as explanatory variables, the statistical analysis results in a static distribution model of fish habitat. Such an approach, which differs from a mechanistic approach, assumes equilibrium in the habitat occupation and results in the characterisation of realised habitats (Guisan and Zimmerman, 2000). Implementation of the regression methodology generally involves some difficulties related to noise in the data and to the choice of the environmental parameters. Noise in the data was addressed by modelling the statistical distribution of the response variable by using generalised linear and/or additive models (e.g., Maravelias and Reid, 1997), regression quantiles (Cade et al., 1999) or cumulative distribution tests (Perry and Smith, 1994). The choice of environmental parameters means building the static statistical model with indirect parameters describing biogeographical pattern or with direct parameters that closely relate the physiological processes at work, making the model more mechanistic and therefore perhaps better fitted but also less transportable (e.g. Guisan and Zimmerman, 2000). In this study, we first characterised structure and pattern in the hydro-plankton environmental parameters using static clustering methods. Then we tested how fish abundance related to this environmental pattern, thus building a simple habitat statistical model. Rather than particular environmental parameters, we used structure in the set of parameters, thus relating the general pattern in the environment with that in the fish.

Fish environmental measurements performed during routine pelagic fisheries surveys are usually indirect crude parameters-e.g. temperature and salinity profiles as well as vertically integrated biomass estimates of phytoplankton and zooplankton. In spring 2000, the fisheries acoustic pelagic survey performed by IFREMER on board R/V "Thalassa" was used as a platform for an extensive characterisation of the structure of the pelagic ecosystem on a large scale over the entire French shelf of the Bay of Biscay. Four major compartments were studied: hydrology, nutrients, primary producers and mesozooplankton. In all, 59 variables were measured in the four compartments which related to the standing stocks as well as to the trophic linkage between compartments. The study had three objectives. The first was to provide an integrated characterisation of hydro-plankton conditions based on correlation structure between variables from the different ecosystem compartments. To do so we used a multitable factor analysis. The method appropriately accounted for the correlation structure within and between compartments. Then clustering in the factorial space was used to group and map the stations. Hydro-plankton groups of stations served as integrated descriptors of the pelagic ecosystem. The second objective of the paper was to characterise the relation between the fish spatial distribution and its trophic environment, characterised by the hydroplankton groups of stations. Standard statistical tests were used to do this. Finally, a small set of hydroplankton variables that are routinely collected during fisheries surveys was tested for its ability to evidence the structure observed with the extensive set of variables. Correlation of variables with the principal components was used to do this.

\section{MATERIALS AND METHODS}

\section{Multi-disciplinary survey}

The fisheries survey PEL2000 on board R/V "Thalassa" aimed at assessing anchovy and sardine stocks in ICES areas VIIIa and VIIIb made a fisheries pelagic ecosystem survey by combining the routine day-time fish acoustic survey with an extensive hydro-plankton survey during night time. The following major operations were conducted (Fig. 1): fish echo-integration and mid-water identification trawl hauls were undertaken during day time, a continuous underway fish egg sampler (CUFES, Checkley et al., 1997) was operated during night and day, and CTD 

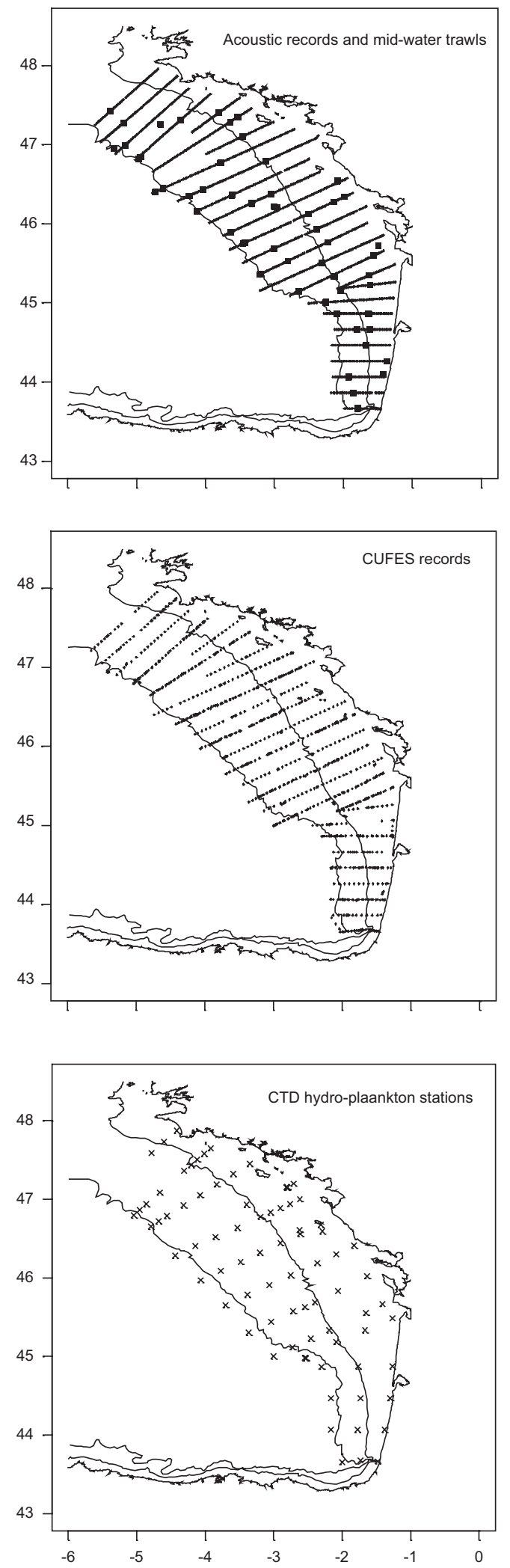

FIG. 1. - Sampling designs for the fish (acoustics), their eggs (CUFES), and CTD hydro-plankton stations during the IFREMER pelagic survey performed in may 2000 (PEL2000) with R/V "Thalassa".

casts were performed during night time, together with the collection of water and plankton at CTD hydroplankton stations. The survey was designed with parallel transects spaced regularly crossing the entire width of the shelf from $44^{\circ} \mathrm{N}$ (Gouf de Cap Breton) to $48^{\circ} \mathrm{N}$ (Pointe du Ratz). Every other transect was also sampled during night time, allowing for night CUFES sampling and regularly spaced hydro-plankton CTD stations. The survey lasted 5 weeks, starting in early May in the south and finishing in June in the North. The set of the 19 hydro-plankton variables used in this work is presented in Table 1 and their basic statistics in Table 2.

\section{Hydrology and turbidity}

Temperature, salinity, density and fluorescence vertical profiles were obtained using CTD casts

TABLE 1. - List of variables used in the present work in the different ecological compartments. All variables were measured except Cbact/Cphyto, which was estimated by using standard carbon content per cell taken from the literature.

Ecological compartment Variables

Hydrology

Primary producers

Meso-zooplankton

Fish
Ts: surface temperature $\left({ }^{\circ} \mathrm{C}\right)$

Ss: surface salinity (psu)

Tf: bottom temperature $\left({ }^{\circ} \mathrm{C}\right)$

Zmel: depth of upper layer (m)

NTU: surface turbidity (arbitrary units)

NOx: nitrates and nitrites abundance (millimole $\mathrm{m}^{-2}$ )

PO4: phosphate abundance (millimole $\mathrm{m}^{-2}$ )

NH4: ammonium abundance (millimole $\mathrm{m}^{-2}$ )

$\mathrm{NOx} / \mathrm{PO} 4$ : ratio of nitrates and nitrites over phosphates

GLC/PROT: ratio of glucids to proteins in particulate organic matter

CHL20: chlorophyll $a>20 u \mathrm{~m}\left(\mathrm{mg} \mathrm{m}^{-2}\right)$

CHL320: chlorophyll a ranging 3-20 $\mu \mathrm{m}$ $\left(\mathrm{mg} \mathrm{m}^{-2}\right)$

CHL3: chlorophyll $a<3 \mu \mathrm{m}\left(\mathrm{mg} \mathrm{m}^{-2}\right)$

Cbact/Cphyto: ratio of carbon in bacteria to that in phytoplankton

Cmicrob/POC: ratio of carbon in living cells to that in particulate organic carbon

PK: Pyruvate kinase specific activity in water column $\left(\mathrm{mg} \mathrm{mn}^{-1} \mathrm{~g}^{-1}\right)$

TRYP: trypsine specific activity in water column $\left(\mathrm{mg} \mathrm{mn}^{-1} \mathrm{~g}^{-1}\right)$

ATC: Aspartate trans-carbamylase specific activity in water column $\left(\mathrm{mg} \mathrm{mn}^{-1} \mathrm{~g}^{-1}\right)$

PROTm2: protein abundance equivalent to referenced bovine serum $\left(\mathrm{mg} \mathrm{m}^{-2}\right)$

Anchovy abundance $\left(10^{3} \mathrm{~kg} \mathrm{~nm}^{-2}\right)$

Sardine abundance $\left(10^{3} \mathrm{~kg} \mathrm{~nm}^{-2}\right)$

Anchovy egg density at $3 \mathrm{~m}$ depth (egg $10 \mathrm{~m}^{-3}$ )

Sardine egg density at $3 \mathrm{~m}$ depth (egg $10 \mathrm{~m}^{-3}$ ) 
TABLE 2. - Basic statistics of the variables collected at the N=43 CTD hydro-plankton stations. Variable codes and units are in Table 1.

\begin{tabular}{|c|c|c|c|c|c|}
\hline Ecological compartment & Variable & Mean & Standard variation & Minimum & Maximum \\
\hline Hydrology & $\begin{array}{c}\text { Ts } \\
\text { Ss } \\
\text { Tf } \\
\text { Zmel } \\
\text { NTU }\end{array}$ & $\begin{array}{c}13.03 \\
34.51 \\
11.93 \\
22.51 \\
0.35\end{array}$ & $\begin{array}{c}0.64 \\
1.18 \\
0.42 \\
15.47 \\
0.42\end{array}$ & $\begin{array}{c}11.98 \\
31.10 \\
11.06 \\
6.50 \\
0\end{array}$ & $\begin{array}{c}14.60 \\
35.62 \\
13.32 \\
66.50 \\
2.30\end{array}$ \\
\hline Nutrients & $\begin{array}{c}\text { NOx } \\
\text { PO4 } \\
\text { NH4 } \\
\text { NOx/PO4 }\end{array}$ & $\begin{array}{c}74.40 \\
1.66 \\
9.13 \\
90.74\end{array}$ & $\begin{array}{c}70.27 \\
1.25 \\
6.13 \\
152.21\end{array}$ & $\begin{array}{l}11.00 \\
0.10 \\
0.30 \\
5.00\end{array}$ & $\begin{array}{c}280.00 \\
5.40 \\
31.00 \\
845.00\end{array}$ \\
\hline Primary Producers & $\begin{array}{c}\text { GLC/PROT } \\
\text { CHL20 } \\
\text { CHL320 } \\
\text { CHL3 } \\
\text { Cbact/Cphyto } \\
\text { Cmicrob/POC }\end{array}$ & $\begin{array}{c}1.03 \\
14.41 \\
8.75 \\
6.62 \\
22.26 \\
38.49\end{array}$ & $\begin{array}{c}0.33 \\
9.47 \\
8.69 \\
4.70 \\
10.10 \\
11.59\end{array}$ & $\begin{array}{c}0.54 \\
0 \\
0 \\
0 \\
7.00 \\
20.00\end{array}$ & $\begin{array}{c}1.78 \\
35.00 \\
54.30 \\
18.00 \\
50.00 \\
70.00\end{array}$ \\
\hline Meso-zooplankton & $\begin{array}{c}\text { PK } \\
\text { TRYP } \\
\text { ATC } \\
\text { PROTm2 }\end{array}$ & $\begin{array}{c}0.35 \\
4.16 \\
0.37 \\
858.29\end{array}$ & $\begin{array}{c}0.29 \\
1.12 \\
0.41 \\
457.13\end{array}$ & $\begin{array}{c}0.01 \\
2.13 \\
0 \\
120.36\end{array}$ & $\begin{array}{c}1.16 \\
8.46 \\
1.63 \\
1990.80\end{array}$ \\
\hline
\end{tabular}

equipped with a rosette at hydro-plankton stations (Fig. 1). For this analysis we considered surface temperature and salinity and bottom temperature. The depth of the maximum density gradient along the density profile estimated the thickness of the mixed layer. Surface water turbidity was estimated by analysing the optical properties of a surface water sample (Froidefond et al., 2002).

\section{Nutrients and primary producers}

Water samples were taken at five depths for measurements of nutrients, chlorophyll, and bacteria. For nutrients, seawater samples were filtered on glass fibre filters (Whatman GF/F) with a syringe filtration system. Phosphate was analysed onboard immediately after sampling on a spectrophotometer (Shimadzu UV-1601) with a $10 \mathrm{~cm}$ optical path cell. Samples for nitrate, nitrite and silicate measurements were stored in polyethylene flasks, frozen $\left(-25^{\circ} \mathrm{C}\right)$ and analysed later in the laboratory on a Skalar autoanalyser. Phosphate, nitrate, nitrite and silicate concentrations were determined according to the classical methods described by Strickland and Parsons (1972), with the respective detection limit of $0.02,0.05,0.03$, and $0.1 \mu \mathrm{M}$ and the respective precision of $0.01,0.05,0.02$ and $0.1 \mu \mathrm{M}$. Total chlorophyll $a$ (Chla) and phaeopigments (Phae) were determined by filtration on $25 \mathrm{~mm}$ Whatman GFF of seawater samples (generally $100 \mathrm{ml}$ ). Size fractionated chlorophyll $a$ was determined by sequential filtration on a $20 \mu \mathrm{m}$ nylon sieve and $3 \mu \mathrm{m}$ nuclepore polycarbonate filters. Filters were frozen and analysed later by the fluorometric acidification procedure in $100 \%$ methanol extracts (Holm-Hansen et al., 1965, modified by Holm Hansen and Rieman, 1978). Sea water samples for bacterial counts were preserved with boratebuffered formaldehyde (2\% final concentration). Bacteria were enumerated by direct epifluorescent counting after staining with DAPI (Porter and Fieg, 1980). Particulate organic matter was collected by filtration through precombust glass fibre filters ( Whatman $\mathrm{GF} / \mathrm{F}$ ) to determine particulate organic carbon (and nitrogen) (POC), total carbohydrate and protein. Samples were stored frozen until analysis. POC filters were fumed overnight with $\mathrm{HCl}$ to remove the inorganic carbon, and then the amount of $\mathrm{C}$ and $\mathrm{N}$ was determined by combustion in a $\mathrm{CN}$ analyser (carlo Erba model 1500). Proteins were estimated with constitutive amino acids freed by acid hydrolysis $\left(5.8 \mathrm{~N} \mathrm{HCl}\right.$ for $24 \mathrm{~h}$ at $\left.105^{\circ} \mathrm{C}\right)$; amino acids were measured by fluorescence of their orthophthaldialdehyde derivatives (Petty et al., 1982). Particulate carbohydrate was estimated after hydrolysis $\left(\mathrm{H} 2 \mathrm{SO} 42 \mathrm{~N}\right.$ for $4 \mathrm{~h}$ at $100^{\circ} \mathrm{C}$ ) by the phenol sulfuric method (Dubois et al., 1956). The depth at which $1 \%$ of surface light was attained determined the euphotic layer. Abundance for each variable was integrated vertically in the euphotic layer. 


\section{Meso-zooplankton}

Bottom to surface vertical hauls were performed using a WP2 net with a $200 \mu \mathrm{m}$ mesh at CTD stations (Fig. 1). The macrozooplankton, when present, was eliminated by sieving through a $5 \mathrm{~mm}$ mesh. The sample was ground in iced distilled water with a Polytron and immediately frozen in liquid nitrogen; it was thereafter stored at $-80{ }^{\circ} \mathrm{C}$ until analysis in the laboratory. After thawing, the crude extract was homogenised with a Potter-Elvehjem homogeniser and centrifuged $\left(10 \mathrm{mn}\right.$ at $\left.4000 \mathrm{rev} . \mathrm{mn}^{-1}, 3^{\circ} \mathrm{C}\right)$. An aliquot of $200 \mu \mathrm{l}$ of supernatant fluid was preserved frozen $\left(-40^{\circ} \mathrm{C}\right)$ and later used for enzyme assay and protein determination in the laboratory. Protein mass corresponded to the vertical integrated biomass (mg $\left.\mathrm{m}^{-2}\right)$. Specific enzyme activity $\left(\mathrm{mg} \mathrm{m}^{-1} \mathrm{~g}^{-1}\right)$ was estimated by dividing enzyme activity (mass of substrate transformed per unit time, $\mathrm{mg} \mathrm{mn}^{-1}$ ) by the protein mass of the aliquot taken for the measurement. Enzyme activity was an indicator for the whole zooplankton community of the major metabolic processes at work. Three enzymes were considered: trypsine (Samain et al., 1977), pyruvate kinase (Bergeron and Herbland, 2001) and aspartate transcarbamylase (ATC: Bergeron, 1992). Trypsin activity was estimated by the classical "BAPNA method" adapted to zooplankton extracts by Samain et al. (1977), pyruvate kinase activity according to Bergeron and Herbland (2001), and ATC activity as initially described by Bergeron and Alayse-Danet (1981) and revised by Biegala and Bergeron (1998). Trypsine activity indicated intensity of proteolytic activity. Pyruvate kinase activity indicated intensity of glucid catabolic activity. The relative importance between trypsine and pyruvate kinase activities indicated the trophic link between mesozooplankton and its lower trophic level because a developed microzooplankton loop was expected to favour high proteolytic activity and a phytoplankton bloom was expected to favour glucid catabolism. ATC activity indicated the (de novo) productivity of mesozooplankton.

\section{Fish}

The acoustic survey design consisted in cross-shelf transect lines from coast (20 m depth) to shelf break (250 m depth) sampled during day time at 10 knots (Fig. 1). Transects were parallel and regularly spaced, with an inter-transect distance of 12 nautical miles (12 $\mathrm{nm})$. The acoustic equipment was a hull-mounted SIM-
RAD EK500 $38 \mathrm{kHz}$ echo-sounder. Expert scrutiny of the echogram together with targeted mid-water trawl hauls were employed to identify echo-traces to species. Fish back-scatter was summed along the vertical dimension and averaged along the horizontal dimension every $1 \mathrm{~nm}$ (6 minutes at 10 knots), resulting in echointegrated energy $\left(\mathrm{mV}^{2} \mathrm{~m}^{2}\right)$ per elementary sampling distance unit (ESDU) of one nautical mile $(1 \mathrm{~nm})$ along the track. Identification trawl hauls were undertaken conditioned to particular acoustic images (sequences of consecutive ESDUs) which during the survey were considered as representative of communities of echotraces and thus of species assemblages. The fish caught in the mid-water pelagic trawl hauls were used to estimate the species proportions in abundance and the weight-length keys. These biological parameters were used to estimate a species echo-integration factor which was in turn used to estimate fish species density by multiplying the factor by the total fish back-scatter (for more details about this survey, see e.g. Petitgas et al., 2003). Anchovy and sardine density (metric tons $\mathrm{nm}^{-2}$ ) was estimated for each $1 \mathrm{~nm}$ ESDU.

\section{Fish eggs}

The CUFES pump was mounted at the end of a pipe at $3 \mathrm{~m}$ depth installed on the starboard side of the $\mathrm{R} / \mathrm{V}$ "Thalassa”. Pumping occurred horizontally at the limit of the turbulence zone surrounding the hull of the vessel. CUFES was operated 'underway' during day acoustic surveying and at night between CTD stations and during CTD stations (Fig. 1). The water was filtered on $500 \mu \mathrm{m}$ nylon mesh. The underway CUFES samples were taken every $3 \mathrm{~nm}$ (18 minutes at 10 knots) by removing the collector and placing another one for the next sample. The eggs were preserved in $7 \%$ formaldehyde, identified to three categories (sardine, anchovy, all other species) and counted. The CUFES pump flow was measured continuously and the sample duration was recorded allowing for the conversion of egg numbers to egg concentrations. Egg density (egg $10 \mathrm{~m}^{-3}$ ) at $3 \mathrm{~m}$ depth was estimated for each CUFES sample for sardine and anchovy.

\section{Statistical analysis methods}

\section{Multiple Factor Analysis and hydro-plankton groups of stations}

Multiple Factor Analysis (MFA, Dazy and Labarzic, 1996; Lebart et al., 1995) was specially 
designed to analyse the multivariate structure of $\mathrm{N}$ individuals when the variables characterising them are grouped in $\mathrm{T}$ compartments. Here, individuals are the CTD stations $(\mathrm{N}=43)$ and groups of variables $(\mathrm{T}=4)$ are ecological compartments (hydrology, nutrients, primary producers and zooplankton consumers). The method constructs a factorial space named the compromise in which to represent all variables and the T clouds of $\mathrm{N}$ stations. The method proceeds in two steps. First, principal component analysis (PCA) is performed for each compartment (partial matrix) and the first eigenvalue serves to appropriately weight the variables in that compartment. The weighting thus depends on the internal structure of the compartment to which the variable belongs. In the second step, a second PCA is performed on the weighted variables and this allows the compromise factorial space to be constructed. Because of the weighting, no compartment by itself can influence the overall structure of the compromise. The weighting by the first eigenvalue in each compartment provides essential mathematical properties for the compromise factorial space: (i) the compromise is the factorial space which is geometrically closest to each compartment factorial space; (ii) the inter-compartment structure ( $\mathrm{T}$ points), the intra-compartment structure ( $\mathrm{T}$ clouds of $\mathrm{N}$ points) and the structure between all variables can all be represented and analysed in the one compromise space; and (iii) the axes of the compromise factorial space can be interpreted as in PCA by the correlation of active or passive variables with the axes. For each individual station, its trajectory between the compartments can be analysed and its compromise position estimated. Clustering of the compromise stations was performed in the factorial compromise space using hierarchical clustering (compact method) on the compromise station scores. Computations were undertaken using SPAD software (CISIA inc.). The MFA was applied on the centred and normed CTD hydro-plankton 19 variables (Tables 1 and 2). The MFA was used instead of a single PCA on all the variables because we wanted to classify the stations using all compartments with similar weights in the analysis.

\section{Importance of certain variables}

Fish environmental variables typically monitored during pelagic fisheries surveys form a small set, i.e. temperature, salinity and standing biomass in the phytoplankton (Chlorophyll a) and zooplankton (proteins). A PCA was performed on the matrix made of these variables collected at the CTD stations and its factorial axes were projected in the compromise space of the MFA as passive variables. Their correlation with the MFA compromise factorial axes was estimated. Also, stations were grouped in the factorial space of the small set of variables. Mapping the groups allowed for a visual comparison between the MFA on the extensive set and the PCA on the small set.

\section{Relationship between hydro-plankton groups and the distribution of adult fish and their eggs}

Hydro-plankton factorial axes provided a synthetic description of the structure and productivity of the ecosystem. The relation of the fish not to individual variables but to synthetic descriptors was tested for. Each acoustic ESDU and each CUFES sample was attributed the code of the hydro-plankton group that belonged to its nearest CTD station. Mean fish and egg density for sardine and anchovy in each hydro-plankton group was estimated. Differences between group means were tested by a multiple comparison procedure for one-way analysis of variance with unequal sample size. The Tukey test was used as it is claimed to be conservative as well as robust to departures from population normality and homogeneity in variance (Zar, 1996). The pair-wise statistic $q$ of the Tukey test (standardised difference in means between groups) was tested against a critical value $q_{\alpha, v, k}$ (tables in Zar, 1996): if $q$ was greater than the critical value then equality in group means was rejected with significance level $\alpha$ $(\alpha=0.05) . q$ depended on the significance level $\alpha$, the number of samples $n$, the number of groups $k$, and the error degrees of freedom $v(v=n-k)$.

\section{RESULTS}

\section{Hydro-plankton groups of stations}

The first 4 principal components of the compromise space represented nearly $59 \%$ of total variance and the first 6 represented $75 \%$, meaning that the variables in the different compartments displayed a coherent structure. After several trials, clustering of the hydro-plankton stations was performed using station scores along the first 4 prin- 


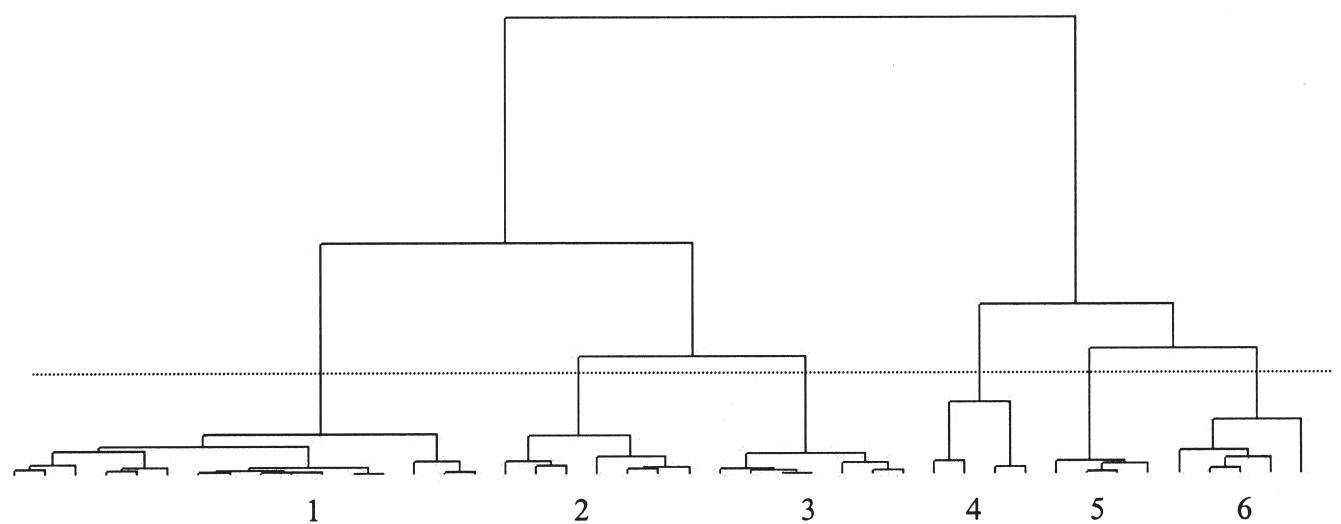

FIG. 2. - Hierarchical clustering of the compromise point for each hydro-plankton station in the compromise factorial space of the MFA. The dashed line represents the cut-off which defined 6 groups of stations.

cipal components. By choosing a threshold on the dendrogram, six groups of stations were defined (Fig. 2, Fig. 3), showing a strong spatial pattern. There were first two major groups (groups 1, 2, 3 and groups $4,5,6)$ which revealed a coast to offshore gradient. Then, a southern-northern gradient was evidenced in two steps. It first involved the shelf-break and mid-shelf (separation between groups 2 and 3), then it also involved the coastal area (separation between groups 4 and groups 5 and 6). The southern-northern gradient was thus more important on the shelf than in the coastal area. Groups 5 and 6 separated coastal waters from those under direct influence from the river discharges.

\section{Interpretation of hydro-plankton groups of stations}

For each variable, we tested whether the variable values in each group were a random sample from the pooled sample across all groups. This was achieved by comparing the group mean to the overall mean for each variable and group with a t-test at risk 0.05 (Zar, 1996). Those variables which had a

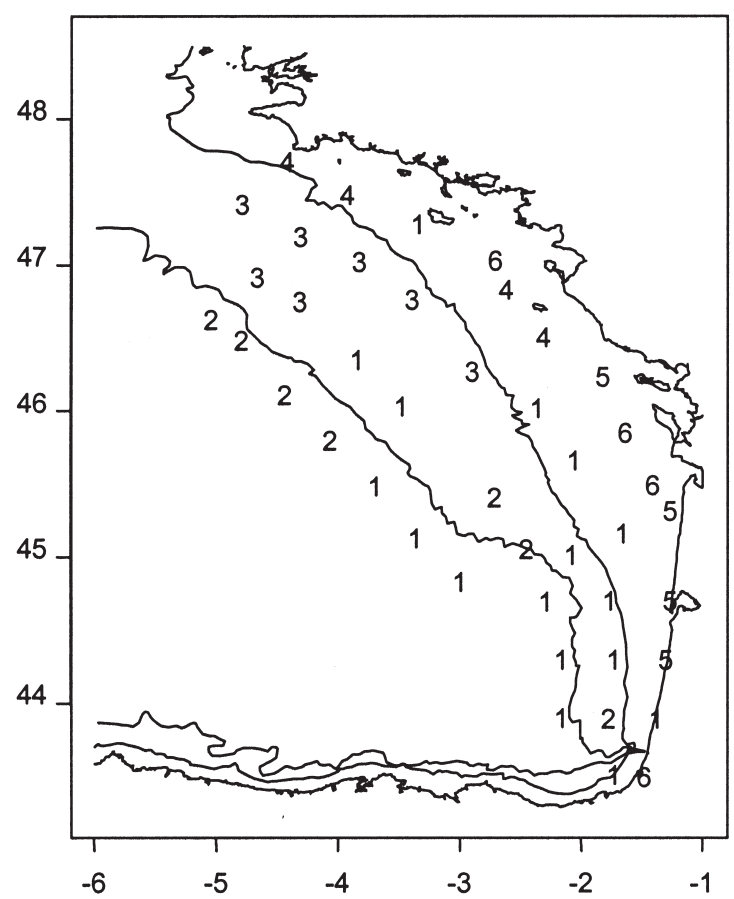

AFM on extensive list

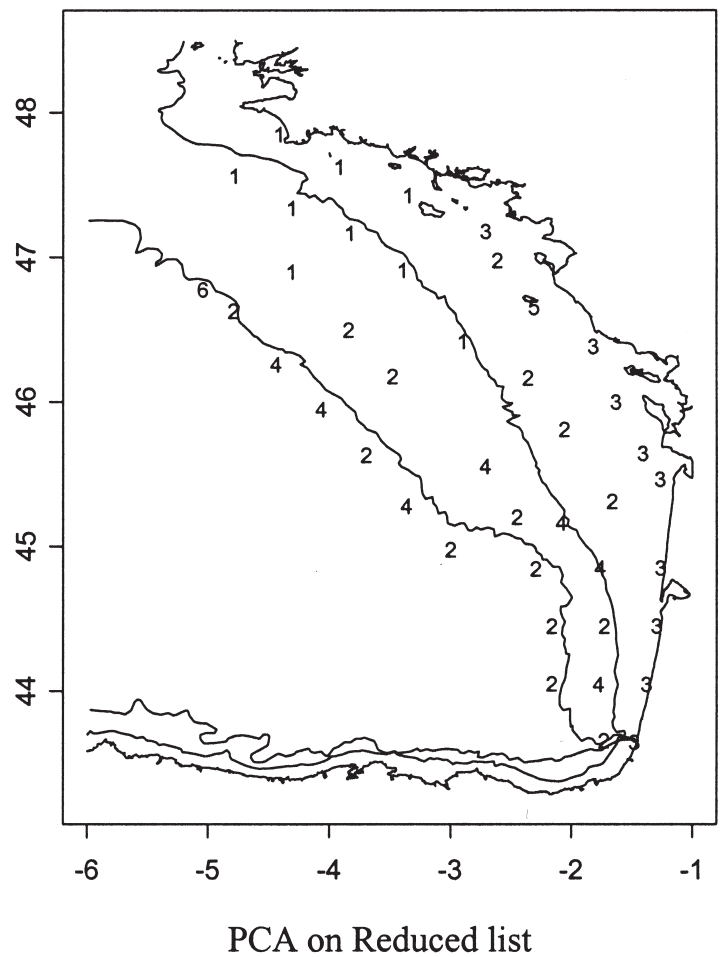

FIG. 3. - Map of groups of hydro-plankton stations. Left: groups obtained by using the extensive set of variables (Table 1), applying MFA and clustering. Right: groups obtained by using the small set of variables, applying PCA and clustering. Codes of hydro-plankton groups are not the same in the two figures. 
TABLE 3. - Summary representation of testing for each variable whether the group mean is significantly different (t-test at risk 0.05$)$ to the overall mean. +/-: significantly higher/lower group mean in comparison to overall mean.

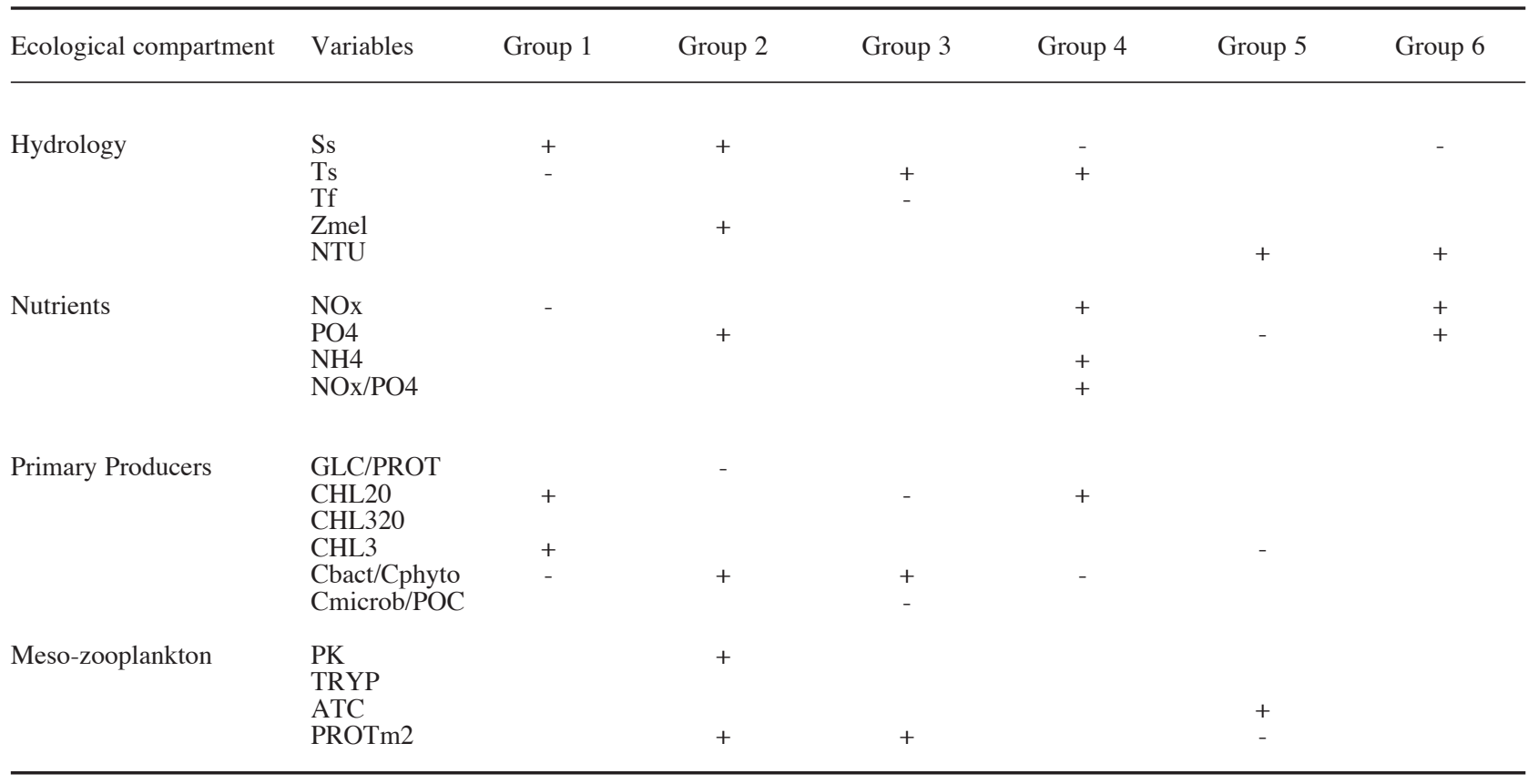

significantly higher/lower group mean than the overall mean were characteristic of the group of stations considered (Table 3). Group 6 was characterised by low salinity, high nutrients and high turbidity. Group 5 was coastal and southern and was characterised by high turbidity, low phosphates, low abundance of small phytoplankton (chl3), high zooplankton productivity and low zooplankton biomass. It seemed that the ecosystem in group 5 was in an advanced state in the seasonal evolution: previous phytoplankton blooms had utilised the phosphates, phytoplankton and zooplankton abundance were low but zooplankton showed high productivity. Group 4 was coastal and northern and was characterised by low surface salinity, high surface temperature, a major nutrient charge for $\mathrm{N}$, an N/P ratio in favour of $\mathrm{N}$, high abundance of large phytoplankton (chl20) and low bacteria abundance. It seemed that the ecosystem in group 4 was beginning its seasonal evolution with a phytoplankton bloom of large cells. Group 3 was characteristic of the mid-shelf in northern Biscay. It was characterised by high surface temperature, low bottom temperature (characteristic of the structure known as the "Bourrelet froid"- - see, e.g., Koutsikopoulos and Le Cann, 1996), low abundance of large phytoplankton (chl20), high relative abundance of bacteria, more carbon in the non-living particular organic matter (Cmicrob/POC), and high abun- dance of zooplankton. A month before the survey at the location of group 3, a major phytoplankton bloom developed which was traced by ocean colour satellite imagery (F. Gohin, pers. comm.). The ecosystem in group 3 was in a post bloom situation, with small cell primary producers, a major charge of organic matter and high abundance of zooplankton. The higher surface temperature in northern Biscay (groups 3 and 5) in comparison with that in southern Biscay was explained by the fact that the survey progressed from south to north together with the seasonal surface warming. Group 1 was located mid-shelf and at shelf-break in southern Biscay. It was characterised by high surface salinity, low surface temperature, high abundance of phytoplankton (both chl20 and chl3), and low relative abundance of bacteria. It is assumed that for the ecosystem in group 1 phytoplankton blooms were repetitive, explaining the presence of large and small phytoplankton. Group 2 was located mainly at the shelf-break in northern Biscay and also on the outer shelf in southern Biscay. It was characterised by high surface salinity, a thick upper mixed layer, high abundance of phosphates, high relative abundance of bacteria, high glucid catabolic activity of zooplankton and high zooplankton abundance. The importance of bacteria and zooplankton would attest that the phytoplankton bloom was past. 

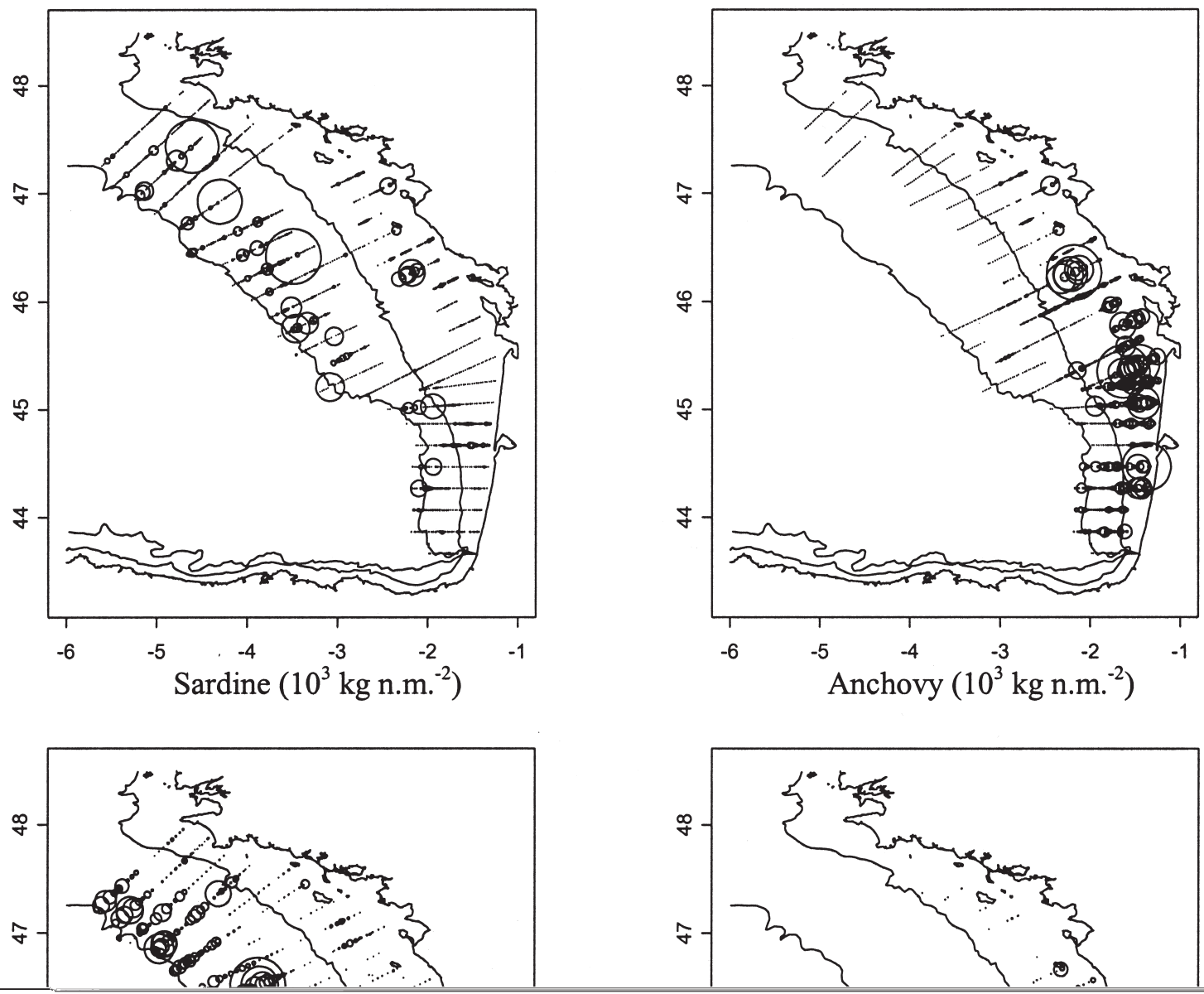

FIG. 4. - Maps of sardine and anchovy derived by echo-integration and of their eggs derived by CUFES. On each map, circle radius is proportional to the sample value and relative to the maximum value.

Sardine and anchovy distributions in relation to hydro-plankton groups

Maps of fish abundance and the density of their eggs (Fig. 4) evidenced a strong spatial pattern for anchovy and sardine. Sardine was distributed along the shelf-break, on the outer shelf and at the coast (off Vendée: $46-47^{\circ} \mathrm{N}$; off Arcachon: $44^{\circ} 30^{\top} \mathrm{N}$ ). Their eggs followed this distribution except that there were no eggs corresponding to the coastal distribution of sardine off Vendée. Sardine eggs were mainly located along the shelf-break, on the outer shelf in northern Biscay, and on the shelf off the Gironde estuary. Anchovy had a more restricted spatial distribution and was located mainly in southern Biscay (south of $46^{\circ} 30^{\prime} \mathrm{N}$ ) on the inner shelf north of the Gironde estuary and covering the entire shelf south of the Gironde (shelf of Les Landes, 44- 
TABLE 4. - Mean fish density $\bar{X}_{G}$ of sardine and anchovy in hydro-plankton station group G, for adult fish (metric tons per square nautical mile) and eggs (numbers per ten cubic meters). Group codes $G$ are the same ones as in Table 3, Figure 2 and Figure 3 (left). $k$ : number of groups; $s^{2}$ : error mean square; $v$ : error degrees of freedom ( $v=n-k$, with $\mathrm{n}$ being the number of sample values).

\begin{tabular}{lccccccccc}
\hline & $k$ & \multirow{2}{*}{$s^{2}$} & $v$ & $\bar{X}_{1}$ & $\bar{X}_{2}$ & $\bar{X}_{3}$ & $\bar{X}_{4}$ & $\bar{X}_{5}$ & $\bar{X}_{6}$ \\
\hline Sardine eggs & 6 & 3703 & 972 & 133.1 & 146.3 & 95.8 & 33.3 & 37.9 & 38.7 \\
Anchovy eggs & 6 & 345 & 972 & 11.7 & 2.4 & 0.1 & 2.1 & 4.2 & 15.1 \\
Sardine adults & 6 & 12165 & 1557 & 29.1 & 25.8 & 34.3 & 16.9 & 8.5 & 45.2 \\
Anchovy adults & 6 & 348 & 1557 & 9.1 & 1.9 & 0.1 & 2.8 & 31.6 & 18.4 \\
\hline
\end{tabular}

$\left.45^{\circ} 30^{\prime} \mathrm{N}\right)$. Anchovy eggs followed the fish distribution and were located along the coast of Vendée, on the shelf off Gironde and on the outer shelf off Les Landes. Over the range of the fish spatial distributions, the hydro-plankton groups formed a patchwork of ecosystem structure and productivity to which the fish responded (Table 4, Fig. 5). Anchovy had a significantly greater abundance in hydroplankton groups 5 and 6 (river plumes and coast south) and had a southern distribution (groups 5, 6, 1 ), meaning that anchovy was restricted to particular habitats. In constrast, sardine was distributed across all groups with no significant difference in abundance between groups, meaning that it occupied a larger range of habitats than anchovy. Anchovy eggs were confined in the same habitats (i.e. groups of stations) as the adult fish, showing greater abundance in groups 6, 1 and 5. Sardine eggs had significantly greater abundance in groups 1,2 and 3, meaning they were not distributed in the coastal habitats (groups 4, $5,6)$. Consequently, sardine eggs were more confined to particular habitats than the sardine fish.
Hydro-plankton characterised with a small set of parameters

During routine acoustic pelagic fisheries surveys in Biscay, it is common to record at hydro-plankton stations the hydrology and fluorescence profiles by CTD casts and zooplankton abundance in vertical WP2 net hauls. Thus, the small set of variables considered was surface and bottom temperatures, surface salinity, depth of mixed upper layer, total chlorophyll $a$, and zooplankton abundance (Ts, Ss, Tf, Zmel2, Chl20+Chl320+Chl3, PROTm2). The projection of the principal components $c_{i}(i=1, \ldots 6)$ of this small set in the factorial space of the MFA showed that they were well correlated with the factorial axes of the MFA (Table 5), in particular with the 4 first axes which were used to make the classification of stations. Thus, similar hydro-plankton groups were to be expected if clustering of the stations was performed using the small set of variables. Now the stations were clustered using the 6 principal axes of the PCA of the small set and 6 groups

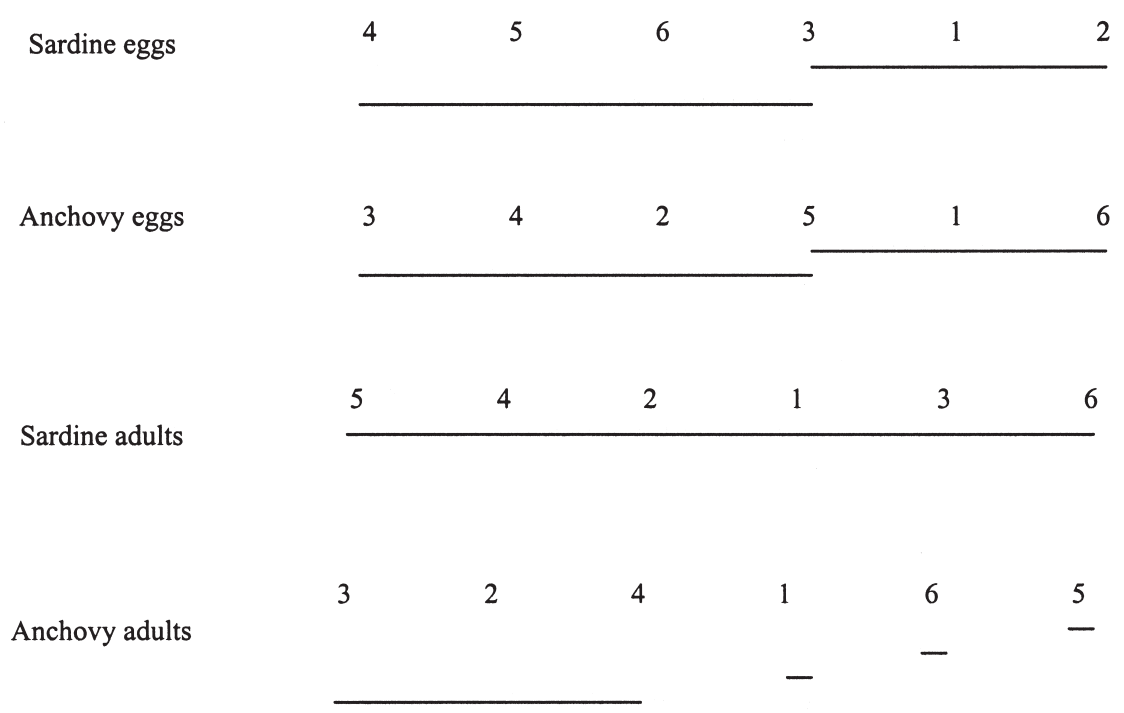

FIG. 5. - Schematic representation of the distribution of fish and egg density within the hydro-plankton groups. Group numbers are ordered by ascending order of density. Horizontal bars are separated to represent the significantly different group means according to the multiple comparison procedure applied (Tukey test). 
TABLE 5. - Coordinates of the principal components (c) for the small set of variables on the principal axes of the Multiple Factorial Analysis (MFA.c) for the extensive set of variables. Sum.cos2 is the sum of the square of the coordinates of the components $\mathrm{c}$ on the four first MFA.c. Sum.cos2 represents the amount of variance in the MFA space contained by each component $\mathrm{c}$.

\begin{tabular}{lcrrrc}
\hline & MFA.c1 & MFA.c2 & MFA.c3 & MFA.c4 & Sum.cos2 \\
\hline c1 & -0.849 & 0.223 & 0.213 & -0.125 & 0.83 \\
c2 & 0.083 & 0.438 & -0.078 & 0.646 & 0.62 \\
c3 & -0.213 & -0.204 & -0.673 & -0.154 & 0.56 \\
c4 & -0.105 & 0.211 & -0.105 & 0.366 & 0.20 \\
c5 & 0.18 & 0.007 & 0.126 & -0.08 & 0.05 \\
c6 & -0.004 & 0.557 & -0.254 & -0.164 & 0.40 \\
\hline
\end{tabular}

were defined from the clustering tree (not shown). The maps of the hydro-plankton groups of stations obtained (i) by MFA on the extensive set of variables and (ii) by PCA on the small set were compared (Fig. 3). With the use of the small set of variables, although the general pattern is reproduced (coast-offshore and north-south spatial organisation), the groups in the coastal areas are not distinguished, i.e. the river plume group coded 6 and the northern Biscay coastal group coded 4 are lost.

\section{DISCUSSION AND CONCLUSION}

In 2000, the French acoustic fisheries survey in Biscay made an ecosystem pelagic survey and an extensive set of variables were measured to characterise the hydro-plankton compartments. The spatial pattern evidenced with the extensive set of hydroplankton variables was first a coast to off-shore gradient, then a north-south gradient on the shelf and finally a north-south gradient near the coast with a particular group under direct influence of river discharge. The results agreed with the spring-time processes at work in Biscay described by Koutsikopoulos and Le Cann (1996).

When groups were defined based on a small set of variables, the geographical pattern of hydroplankton conditions obtained was similar to that obtained with the extensive set of parameters: coast to off-shore gradient and north to south gradient. The sampling scheme of the CTD stations (a grid of stations 20 nautical miles apart) was designed to describe the spatial organisation at a large scale and the result was that an extensive set of variables was not necessary for achieving this goal at this scale of sampling. The major difference concerned the coastal groups: the extensive set of variables allowed a variety of conditions to be identified in coastal waters but the use of the small set of variables collapsed these conditions into a single coastal group. In particular, the group characteristic of river plumes could not be identified with the small set of variables. Size-fractionated chlorophyll $a$ (a proxy for phytoplankton cell size) was an important criteria for identifying the conditions under the direct influence of river discharge.

The groups of hydro-plankton stations were interpreted as characteristics of fish habitats. The fish spatial organisation was related to that of the groups of stations. Anchovy was restricted to southern coastal and southern shelf habitats (groups 5, 6, 1). Sardine was not restricted to any particular habitat, being present in all. Anchovy eggs were distributed in the same habitats as the adult. Sardine eggs were restricted to the shelf and shelf-break habitats (groups 2, 1, 3). The present result on anchovy for year 2000 agreed with that of the spatial distribution of spawning described by Motos et al. (1996) for the years 1991 and 1992.

The present analysis helped to build a simple static habitat distribution model predicting average egg and fish density for particular hydro-plankton conditions for anchovy and sardine in spring. To realistically predict the spatial pattern of the fish based on hydro-plankton characteristics, more years would need to be studied to test whether the groups defined in this study form the set of all possible hydro-plankton conditions and whether the relationship between hydro-plankton conditions and fish density is consistent across the years.

\section{ACKNOWLEDGEMENTS}

This study was a contribution to the French national research program for shelf ecology in Biscay (PNEC-Gascogne). It also contributed to the IFREMER project FOREVAR affiliated to GLOBEC, a module of the IFREMER programme for fisheries ecology integrated research in Biscay (Défi Gascogne). The co-authors were responsible for "data packages" in each ecosystem compartment. We wish to thank all scientists involved at sea and in the laboratory. We also thank the crew of $\mathrm{R} / \mathrm{V}$ "Thalassa" for making such a complete and difficult survey possible. The fisheries part of the survey was partially financed by the European Commission, DG-Fish, under the study project PELASSES nº 99/010. 


\section{REFERENCES}

Bergeron, J.P. - 1992. Variabilité hydrobiologique et productivité secondaire pélagique: une approche par la mesure de l'activité de l'aspartate transcarbamylase. ICES Mar. Sci. Symp., 195: 260-267.

Bergeron, J.P. and A. Herbland. - 2001. Pyruvate kinase activity as index of carbohydrate assimilation by mesozooplankton: an early field implementation in the bay of Biscay, NE Atlantic. $J$. Plankton Res., 23: 157-163.

Bergeron, J.P. and A.M. Alayse-Danet. - 1981. Aspartate transcarbamylase de la coquille Saint-Jacques Pecten maximus L. (Mollusque Lamellibranche): méthode de dosage et variations de l'activité dans le manteau et la gonade. J. Exp. Mar. Biol. Ecol., 50: 99-117.

Biegala, I.C. and J.P. Bergeron. - 1998. Optimal assay conditions for aspartate transcarbamylase (ATCase) activity in mesozooplankton. J. Plankton Res., 20: 1205-1218.

Cade, B., J. Terrel and R. Schroeder. - 1999. Estimating effects of limiting factors with regression quantiles. Ecology, 80: 311-323.

Checkley, D., J.R. Peter, P. Ortner, L. Settle and S. Cummings. 1997. A continuous, underway fish egg sampler. Fish. Oceanog., 6: 58-73.

Dazy, F. and J.F. Le Barzic. - 1996. L'analyse des données évolutives. Editions Technip, Paris.

Dubois, M., K. Gilles, J. Hamilton, P. Rebers P. and F. Smith. 1956. Colorimetric method for determination of sugars and related substances. Anal. Chem., 28: 350-356.

Froidefond, J.M., S. Lavender, P. Laborde, A. Herbland and V. Lafon. - 2002. SeaWiFS data interpretation in a coastal area in the Bay of Biscay. Int. J. Remote Sens., 23: 881-904.

Guisan, A. and N. Zimmermann. - 2000. Predictive habitat distribution models in ecology. Ecol. Model., 135: 147-186.

Holm-Hansen, O., C. Lorenzen, R. Holmes and J. Strickland. 1965. Fluorometric determination of chlorophyll. J. Int. Cons.
Explor. Mer., 30: 3-15.

Holm-Hansen, O. and B. Rieman. - 1978. Chlorophyll a determination: improvements in methodology. Oikos, 30: 438-447.

Lebart, L., A. Morineau and M. Piron. - 1995. Statistique exploratoire multidimensionnelle. Dunod, Paris.

MacLennan, D. and E. Simmonds. - 1992. Fisheries acoustics. Chapman \& Hall, London.

Maravelias, C. and D. Reid. - 1997. Identifying the effects of oceanographic features and zooplankton on pre-spawning herring abundance using generalised additive models. Mar. Ecol. Prog. Ser., 147: 1-9.

Motos, L., A. Uriarte and V. Valencia. - 1996. The spawning environment of the Bay of Biscay anchovy (Engraulis encrasicolus). Sci. Mar., 60(Supl. 2): 117-140.

Perry, R. and S. Smith. - 1994. Identifying habitat associations of marine fishes using survey data: an application to the Northwest Atlantic. Can. J. Fish. Aquat. Sci., 51: 589-602.

Petitgas, P., J. Massé, P. Beillois, E. Lebarbier and A. Le Cann. 2003. Sampling variance of species identification in fisheries acoustic surveys based on automated procedures associating acoustic images and trawl hauls. ICES J. Mar. Sci., 60: 437-445.

Petty R., W. Michel, J. Snow and K. Johnson. - 1982. Determination of total primary amines in sea water and plant nectar with flow injection sample processing and fluorescence detection. Anal. Chim. Acta, 142: 299-304.

Porter, K. and Y. Fieg. - 1980. The use of DAPI for identifying and counting aquatic microflora. Limnol. Oceanogr., 25: 943-948.

Samain, J.F., J.Y. Daniel and J.R. Le Coz. - 1977. Trypsine, amylase et protéines du zooplancton: dosage automatique et manuel. J. Exp. Mar. Biol. Ecol., 29: 279-289.

Strickland, J. and T. Parsons. - 1972. A practical handbook of seawater analysis. Bull.167, $2^{\text {nd }}$ ed, Fish. Res. Board Can., 310pp.

Zar, J. - 1996. Biostatistical analysis. Third Edition. Prentice Hall International, Inc. Upper Saddle River, N.J., USA.

Received September 19, 2002. Accepted November 24, 2004. 